\title{
3-(Piperidin-4-ylmethoxy)pyridine Containing Compounds Are Potent Inhibitors of Lysine Specific Demethylase 1
}

\author{
Fangrui $\mathrm{Wu}^{\# \dagger}$, Chao Zhou ${ }^{\# \dagger}$, Yuan Yao ${ }^{\dagger}$, Liping Wei ${ }^{\dagger}$, Zizhen Feng ${ }^{\dagger}$, Lisheng Deng ${ }^{\dagger}$, and \\ Yongcheng Song ${ }^{*}, t \neq$ \\ † Department of Pharmacology, Baylor College of Medicine, 1 Baylor Plaza, Houston, TX 77030, \\ USA. \\ ‡ Dan L. Duncan Cancer Center, Baylor College of Medicine, 1 Baylor Plaza, Houston, TX 77030, \\ USA. \\ \# These authors contributed equally to this work.
}

\section{Abstract}

Methylation of histone lysine residues plays important roles in gene expression regulation as well as cancer initiation. Lysine specific demethylase 1 (LSD1) is responsible for maintaining balanced methylation levels at histone $\mathrm{H} 3$ lysine 4 (H3K4). LSD1 is a drug target for certain cancers, due to important functions of methylated H3K4 or LSD1 overexpression. We report the design, synthesis and structure activity relationships of 3-(piperidin-4-ylmethoxy)pyridine containing compounds as potent LSD1 inhibitors with $K_{\mathrm{i}}$ values as low as $29 \mathrm{nM}$. These compounds exhibited high selectivity $(>160 \times)$ against related monoamine oxidase A and B. Enzyme kinetics and docking studies suggested they are competitive inhibitors against a dimethylated $\mathrm{H} 3 \mathrm{~K} 4$ substrate and provided a possible binding mode. The potent LSD1 inhibitors can increase cellular H3K4 methylation and strongly inhibit proliferation of several leukemia and solid tumor cells with $\mathrm{EC}_{50}$ values as low as $280 \mathrm{nM}$, while they had negligible effects on normal cells.

\section{INTRODUCTION}

Post-translational modifications of the $\varepsilon$-amino group of histone lysine residues, such as acetylation and methylation, play important roles in gene expression regulation in normal physiology as well as diseases. ${ }^{1-4}$ Small molecule modulators of histone modifying enzymes are therefore chemical probes for biological studies and potentially useful therapeutics for such diseases ${ }^{5-7}$ Histone H3 lysine 4 (H3K4) methylation, including mono-, di- and trimethylation (H3K4me1, 2 and 3), has been found to be generally a biomarker for active gene transcription. ${ }^{8,9}$ Mixed lineage leukemia (MLL), a large, multi-domain protein containing 4,000 amino acids, can methylate H3K4, with its C-terminal SET domain being catalytically active. ${ }^{9-11}$ In addition, cellular $\mathrm{H} 3 \mathrm{~K} 4$ methylation levels are tightly regulated because of their important functions. Lysine specific demethylase 1 (LSD1, also known as

\footnotetext{
*To whom correspondence should be addressed. Address: Department of Pharmacology, Baylor College of Medicine, 1 Baylor Plaza, Houston, TX 77030. Tel: 713-798-7415. ; Email: ysong@ bcm.edu.

Supporting Information Available. Figure S1-S3 and Experimental Section showing detailed compound synthesis and characterization. This material is available free of charge via the Internet at http://pubs.acs.org.
} 
KDM1a) has been found to be a member of an MLL transcription complex. LSD1 catalyzes an oxidative demethylation reaction from $\mathrm{H} 3 \mathrm{~K} 4 \mathrm{me} 1$ and 2 (but not $\mathrm{H} 3 \mathrm{~K} 4 \mathrm{me} 3$ ) and thus counteracts the enzyme function of MLL. ${ }^{12,13}$ Both MLL and LSD1 are essential for hematopoiesis, showing a balanced cellular $\mathrm{H} 3 \mathrm{~K} 4$ methylation is crucial for normal hematopoiesis. ${ }^{11,14}$ In addition, H3K9 ${ }^{15}$ and other proteins such as DNMT1 ${ }^{16}$ were reported as a substrate of LSD1.

Dysregulated histone lysine methylations may lead to a disease, such as cancer. ${ }^{2}$ For example, $\sim 75 \%$ acute leukemia in infants and $10 \%$ of that in adults contain an MLL gene translocation and this subtype of leukemia shows a poor prognosis. ${ }^{17-19}$ All MLL translocations identified to date produce an onco-MLL fusion protein without the C-terminal SET domain, which cannot methylate H3K4. ${ }^{11}$ Rather, the fusion partners can recruit DOT1L, a histone H3 lysine 79 (H3K79) methyltransferase, which causes aberrant H3K79 methylation at MLL target gene loci and overexpression of these genes, eventually leading to the initiation of the leukemia. ${ }^{20-22}$ Pharmacological inhibition of DOT1L has been found to block proliferation of MLL-rearranged leukemia cells, showing effectiveness of the targeted epigenetic therapy. ${ }^{23,24}$

LSD1 is a flavin adenine dinucleotide (FAD) dependent oxidase, related to monoamine oxidase A and B (MAO-A and -B). ${ }^{13}$ Figure 1A schematically shows the mechanism of catalysis of LSD1. Upon binding to LSD1, the methyl group of a methylated histone lysine residue (e.g., H3K4me2) is oxidized by the cofactor FAD, followed by hydrolysis to give formaldehyde and demethylated lysine. $\mathrm{FADH}_{2}$, the reduced form of $\mathrm{FAD}$, is oxidized by $\mathrm{O}_{2}$ in the solvent to give $\mathrm{H}_{2} \mathrm{O}_{2}$ and FAD to complete a catalytic cycle. ${ }^{25}$ A number of LSD1 inhibitors with several chemotypes, including cyclopropylamine, propargylamine, hydrazine and triazole-dithiocarbamate, have been reported in journals and patents, ${ }^{26,27}$ as

representatively shown in Figure 1B. Most LSD1 inhibitors are cyclopropylamine containing compounds, derived from tranylcypromine (1), an inhibitor of MAO-A and -B as well as an FDA-approved anti-depression drug. Mechanistically, the a-C atom of the cyclopropyl ring of these compounds is oxidized, causing opening of the constrained ring followed by covalent link to FAD (Supporting Information Figure S1). ${ }^{25}$ Reversible LSD1 inhibitors have also been reported. ${ }^{26 \mathrm{~b}}$

LSD1 has been suggested to be a drug target for several types of cancers (e.g., prostate and breast) due to its overexpression in these malignancies. ${ }^{28-30}$ In addition, LSD1 was recently found to be required for an MLL-rearranged leukemia. ${ }^{31}$ Knockdown of LSD1 can abrogate the transforming ability of the onco-MLL fusion gene and increase the H3K4me2 levels. Using a cyclopropylamine based LSD1 inhibitor also showed activity against the MLLrearranged leukemia in cell and mouse models. ${ }^{31}$ However, this compound was reported to have severe toxicities. Nonetheless, these previous studies have indicated LSD1 is a validated drug target and more chemo-types of inhibitors are therefore needed. ${ }^{32,33}$

Here, we report the discovery, synthesis and structure activity relationships (SAR) of 3(piperidin-4-ylmethoxy)pyridine containing compounds as potent LSD1 inhibitors. Enzyme kinetics and molecular modeling studies were used to investigate the possible mechanism of inhibition as well as the binding mode of these compounds. Molecular and cell biology 
experiments were performed to characterize the biological activities of selected compounds. During the revision of this manuscript, we noticed that scientists at GlaxoSmithKline found a structurally similar LSD1 inhibitor and presented its preliminary data in the 2013 American Association of Cancer Research annual meeting. ${ }^{34,26 b, 27 i}$

\section{RESULTS AND DISCUSSION}

\section{Inhibitor design and discovery}

Based on the results from previous ${ }^{27 a}$ and our own studies on cyclopropylamine containing inhibitors of LSD1, it is clear that a second basic N-substituent, such as the piperidin-4ylmethyl group (in red dashed cycle, Chart 1) in compound 2, can significantly increase the inhibitory activity as well as selectivity for LSD1. For example, compound $2\left(\mathrm{IC}_{50}=62 \mathrm{nM}\right)$ is $\sim 250$-fold more active against human recombinant LSD1 than compound $\mathbf{1}\left(\mathrm{IC}_{50}: 15.7\right.$ $\mu \mathrm{M}^{31}$ ) and, moreover, the piperidin-4-ylmethyl group enhances the enzyme selectivity for LSD1 by >1,500-folds. Similar features have been observed by us and others ${ }^{27 a}$ for compounds $\mathbf{S 1}$ and $\mathbf{S} 2$ for the (4-methylpiperazin-1-yl)carbonylmethyl group in compound S2 (Supporting Information Figure S2). These data strongly support an important role of these basic amine groups in inhibitor recognition and/or binding to LSD1. However, there has been no structural information as to how these groups bind to LSD1, since X-ray crystallography might not be suited for this study because these groups are to be eliminated upon completion of the reaction (Figure S1). Nevertheless, given its important role in inhibitory potency and selectivity for LSD1, a basic amine group such as piperidin-4ylmethyl should be included for the design of new LSD1 inhibitors.

We wished to find competitive, drug-like inhibitors of LSD1 that do not covalently bind to FAD or the enzyme. Compound $\mathbf{3}$ (Chart 1) was designed, in which the piperidin-4-ylmethyl and the phenyl group in the potent inhibitor $\mathbf{2}$ are retained, while the reactive cyclopropylamine moiety is replaced by a chemically stable pyridine core. Our modeling (docking) study (Figure 2A) predicted that the protonated piperidine amino group (at the physiological $\mathrm{pH}$ ) could form a hydrogen bond with Asp555 and the pyridine ring could have favorable electrostatic and hydrophobic interactions with the flavin ring of FAD as well as Tyr761. Compound $\mathbf{3}$ was found to be inactive presumably due to the large active site of LSD1. Compound 4 was next designed with the rationale that an additional phenyl group could increase the binding affinity to LSD1, as suggested by docking (Figure 2B). The use of the pyrazine ring in $\mathbf{4}$ was intended for quick synthesis (see the Synthesis section below). Compound 4 was found to be a weak inhibitor with an apparent $K_{\mathrm{i}}$ value of $47.8 \mu \mathrm{M}$. We next performed a small scale of SAR studies (described below) based on compound $\mathbf{4}$, which yielded a good inhibitor 5 with a $K_{\mathrm{i}}$ value of $2.3 \mu \mathrm{M}$. Enzyme kinetics studies (described below) suggested that compound $\mathbf{5}$ is a competitive inhibitor of LSD1 against a dimethylated H3K4 peptide substrate. These findings, together with its drug-like chemical structure, show that compound $\mathbf{5}$ represents a promising new scaffold for further inhibitor optimization.

\section{Synthesis}

Scheme 1 illustrates a general method for synthesis of pyrazine containing inhibitors. A commercially available benzil compound was reacted with an equal molar amount of 2- 
aminoacetamide in the presence of sodium hydroxide to give 2-hydroxy-5,6-

diphenylpyrazine. Upon treatment with $\mathrm{POCl}_{3}$, its 2-hydroxy group was converted to a $-\mathrm{Cl}$.

The compound thus obtained was subjected to a substitution reaction using a sodium salt of tert-butyloxycarbonyl (BOC) protected 4-(hydroxymethyl)piperidine. Pyrazine containing inhibitors (such as compound 4 ) were synthesized after deprotection of the BOC group. In addition, treatment of the $\mathrm{BOC}$ protected intermediate compound $(\mathrm{R}=\mathrm{Br})$ with zinc cyanide in the presence of a catalytic amount of $\mathrm{Pd}\left(\mathrm{PPh}_{3}\right)_{4}$ to produce a mixture of mono- and dicyano substituted compounds, which can be carefully separated by column chromatography to give, upon deprotection, compounds $\mathbf{8}$ - 10 (described below).

Scheme 2 shows a general synthesis of 3-(piperidin-4-ylmethoxy)-pyridine containing LSD1 inhibitors (such as compound 5). A Mitsunobu reaction between 5-bromo-6-chloropyridin-3ol and BOC protected 4-(hydroxymethyl)piperidine introduces a BOC-protected 3-

(piperidin-4-ylmethoxy) $\mathrm{R}^{3}$ substituent. A selective Suzuki coupling reaction was performed to give $\mathrm{R}^{5}$-substituted compound, which underwent a second Suzuki coupling reaction with its 6-Cl group to add a $\mathrm{R}^{6}$-substituent. Upon deprotection of the BOC group, 3-(piperidin-4ylmethoxy)pyridine containing compounds $\mathbf{5 , 1 1}-\mathbf{4 0}$ can be obtained. In addition, using the similar methods, related compounds $\mathbf{4 1}$ - $\mathbf{4 5}$ can be readily synthesized (Supporting Information Experimental Section).

\section{SAR studies}

Upon obtaining compound 4 with an apparent $K_{\mathrm{i}}$ value of $47.8 \mu \mathrm{M}$, we synthesized several analogs of 4 shown in Chart 2. Compound 6 with 5,6-di-(4-tolyl) and compound 7 with 5,6di-(4-bromophenyl) substituents are more active $\left(K_{\mathrm{i}}=32.2\right.$ and $26.2 \mu \mathrm{M}$, respectively), showing the two methyl or bromo groups are favorable. Synthesized from $\mathbf{7}$ using a Pdcatalyzed reaction, compound $\mathbf{8}$ with 5,6-di-(4-cyanophenyl) was found to be considerably more active with a $K_{\mathrm{i}}$ of $9.1 \mu \mathrm{M}$. In addition, mono-cyano substituted compounds $\mathbf{9}$ and $\mathbf{1 0}$ were also synthesized, which can be separated by column chromatography. One isomer 9 exhibited potent inhibitory activity against LSD1 with a $K_{\mathrm{i}}$ value of $540 \mathrm{nM}$, while the other isomer $10\left(K_{\mathrm{i}}=16.5 \mu \mathrm{M}\right)$ is less active than compound $\mathbf{8}$. This indicated that 5- and 6substituent in compounds 4, 6 - 10 should be individually optimized for LSD1 inhibition. However, this is not synthetically feasible for compounds with a pyrazine core.

The pyridine core structure, in which the two substituents can be modified separately, was used for SAR studies. Although compound $\mathbf{1 1}$ (Chart 2, which corresponds to the pyrazine compound 4) is inactive, compound $\mathbf{1 2}$ with a $K_{\mathrm{i}}$ value of $4.0 \mu \mathrm{M}$ is a good LSD1 inhibitor and stronger than the corresponding pyrazine compound $\mathbf{8}$. This showed the pyridine core can be a good scaffold for activity optimization.

The 6-position of the pyridine ring was optimized and the results are summarized in Table 1. Compound $\mathbf{5}$ with an unsubstituted 6-phenyl group was found to be slightly more active ( $K_{\mathrm{i}}$ $=2.3 \mu \mathrm{M}$ ) than 12. Compound $\mathbf{1 3}$ having a 4-fluorophenyl group exhibited potent inhibitory activity with a $K_{\mathrm{i}}$ of $220 \mathrm{nM}, \sim 10 \times$ more active than the parent compound $\mathbf{5}$. Adding an additional -F at the 3 - or 2-position in compound $\mathbf{1 4}\left(K_{\mathrm{i}}=570 \mathrm{nM}\right)$ or $\mathbf{1 5}\left(K_{\mathrm{i}}=1.2 \mu \mathrm{M}\right)$, respectively, resulted in a $\sim 2.5 \times$ or $5.5 \times$ activity reduction, suggesting that $3-$ or $2-$ 
substitution of the phenyl ring seems to be disfavored. The 4-trifluoromethyl group in compound 16 considerably enhanced the inhibitory potency to $58 \mathrm{nM}$. Change to a 4-methyl group in compound $17\left(K_{\mathrm{i}}=29 \mathrm{nM}\right)$ further caused a $\sim$-fold activity increase. Move of the methyl group to 3-position in compound $18\left(K_{\mathrm{i}}=800 \mathrm{nM}\right)$ drastically decreased the activity by $\sim 27$-folds, showing again substitution at the 4-position of the 6-phenyl ring is favorable. Compounds 19 and $\mathbf{2 0}$ with a 4-ethyl and 4-isopropyl group, respectively, were found to be $\sim 7 \times$ and $3 \times$ less active $\left(K_{\mathrm{i}}=200\right.$ and $88 \mathrm{nM}$ ) than 17 with a 4-methyl, showing a bigger alkyl group at this position is less favorable. As compared to the most potent inhibitor 17, while compound 21 ( $K_{\mathrm{i}}=740 \mathrm{nM}$ ) having a 4-methoxy group showed a significant activity reduction, compound $\mathbf{2 2}$ with a 4-trifluoromethoxy substituent exhibited a similar inhibitory activity $\left(K_{\mathrm{i}}=46 \mathrm{nM}\right)$. Activities of compounds 23 - 26 indicated that a 6-pyridinyl ring is less favorable than a phenyl ring. Compounds 23 and $\mathbf{2 4}\left(K_{\mathrm{i}}=5.0\right.$ and $\left.3.2 \mu \mathrm{M}\right)$ with a pyridin-4-yl and -3-yl ring, respectively, are slightly less active than is compound $\mathbf{5}\left(K_{\mathrm{i}}=2.3\right.$ $\mu \mathrm{M})$. More noticeably, compound $25\left(K_{\mathrm{i}}=1.8 \mu \mathrm{M}\right)$ with a 4-fluoropyridin-3-yl substituent exhibited a $\sim 8$-fold activity reduction as compared to the corresponding phenyl compound 13. Although the 4-methyl group in compound 26 resulted in a significant activity increase ( $K_{\mathrm{i}}=380 \mathrm{nM}$, as compared to $3.2 \mu \mathrm{M}$ for compound $\mathbf{2 4}$ ), compound 26 is still $\sim 13 \times$ less active than the corresponding phenyl compound 17. In addition, introducing a 3-thiophenyl ring to the 6-position produced compound $\mathbf{2 7}$, which exhibited a comparable inhibitory activity $\left(K_{\mathrm{i}}=2.4 \mu \mathrm{M}\right)$ to that of the phenyl compound $\mathbf{5}$.

Next, compounds $\mathbf{2 8}$ - $\mathbf{4 0}$ were synthesized and tested for LSD1 inhibition for SAR studies of the 5-position of the most potent inhibitor 17. As summarized in Table 1, the 4-cyano substituent of the 5-phenyl ring has turned out to be critically important for LSD1 inhibition. Compound $\mathbf{2 8}$ with a 4-ethynyl group was surprisingly found to suffer from a complete $(>1,700 \times)$ activity loss, despite a similar size of the $\mathrm{R}^{5}$ groups. This could be due to different electrostatic properties between the ethynyl (in 28) and the cyano group (in 17). Compounds 29 and 30 with a 4-carboxy and 4-hydroxymethyl group in the 5-phenyl ring also completely lose inhibitory activities. In addition, compounds 31 - 34, which contain a 4-amide group with a range of steric, hydrophobic and electronic properties, were found to be inactive. Compounds $\mathbf{3 5}$ - $\mathbf{3 8}$ having a 4-aminomethyl group retained some inhibitory activities against LSD1. Compound $\mathbf{3 5}$ with a smaller ethylaminomethyl group is a weak inhibitor with a $K_{\mathrm{i}}$ of $22.3 \mu \mathrm{M}$, while compounds $\mathbf{3 6}$ and $\mathbf{3 7}$ having a bulkier piperidin-1-ylmethyl and morpholin-4-ylmethyl substituent, respectively, are almost inactive. Interestingly, compound 38 with a dibasic, piperazin-1-ylmethyl group is a fairly good inhibitor with a $K_{\mathrm{i}}$ of $7.6 \mu \mathrm{M}$, although it is $>250 \times$ less active than compound $\mathbf{1 7}$ having the corresponding $-\mathrm{CN}$ substituent. Moreover, compared to 17, adding a -F into the 2- and 3-position of the 5-phenyl ring in compounds 39 and $\mathbf{4 0}\left(K_{\mathrm{i}}=220\right.$ and $\left.150 \mathrm{nM}\right)$, respectively, resulted in $\sim 8 \times$ and $5 \times$ activity reductions.

Finally, several compounds shown in Chart 3 were synthesized for the SAR study of the 3(piperidin-4-ylmethoxy)pyridine core structure. Compound $\mathbf{4 1}\left(K_{\mathrm{i}}=4.9 \mu \mathrm{M}\right)$ with a benzene core structure is $\sim 170$-fold less potent than compound 17, suggesting the pyridine core is of importance for the activity. Despite as a racemic mixture, the $650 \mathrm{nM} K_{\mathrm{i}}$ value of compound $\mathbf{4 2}$ shows that the piperidin-3-yl substituent is significantly less favorable than the 
piperidin-4-yl group in 17. Greatly reduced activity of compound $\mathbf{4 3}\left(K_{\mathrm{i}}=1.2 \mu \mathrm{M}\right)$ also indicates that change of an -O- linkage in compound $\mathbf{1 7}$ to an - $\mathrm{NH}$ - is highly disfavored. Loss of activity for compounds $\mathbf{4 4}$ (with a 3-OH group) and $\mathbf{4 5}$ (with a 3-benzyloxy group) clearly shows the critical role of the basic piperidine side chain in LSD1 inhibition.

\section{Enzyme kinetics studies}

A steady-state enzyme kinetics study of compound $\mathbf{5}$, which is a representative compound for this novel series of LSD1 inhibitors, was performed to determine the possible mechanism of action. Since the cofactor FAD has a very high affinity to LSD1, as evidenced by its presence in the enzyme even after a lengthy expression and purification process, the kinetics study was performed against a dimethylated $\mathrm{H} 3 \mathrm{~K} 4$ peptide substrate with a sequence of ARTK(Me2)QTARKSTGGKAPRKQKA. Initial velocities of the LSD1 catalyzed reaction were measured with increasing concentrations of compound $\mathbf{5}$ and the substrate. The program SigmaPlot was used for enzyme kinetics modeling. The reaction rate and ligand concentration data were imported into the program and fitted to either competitive, uncompetitive or noncompetitive inhibition models. The best model, as judged by $R^{2}$ and AICc values, would show the mode of action for the inhibitor. Thus, compound $\mathbf{5}$ was found to be a competitive inhibitor of LSD1 against the substrate, because the kinetics data for 5 were best fitted to the competitive mode of action (Figure 3), as compared to the uncompetitive and noncompetitive fitting (Figure S3).

\section{Docking studies}

We carried out molecular modeling (docking) studies to predict how the most potent inhibitor 17 binds to LSD1. A number of X-ray crystal structures of LSD1 in complex with covalent inhibitors, ${ }^{25,36}$ a reversible inhibitor, ${ }^{37}$ and substrate-like peptide ${ }^{38,39}$ are available for the study. The docking program Glide in Schrödinger Suite molecular modeling software package was used for docking. ${ }^{40}$ The crystal structure (PDB code: 2V1D) of human LSD1 in complex with a $\mathrm{H} 3 \mathrm{~K} 4$ mimetic peptide ${ }^{39}$ (with a $\mathrm{K} 4 \mathrm{M}$ mutation) was used as a docking template, which was prepared by adding hydrogen atoms to the structure, removing the peptide and water molecules, while keeping FAD as an integrated component of the protein. Compound $\mathbf{1 7}$ can be well docked into the active site of LSD1, with its 20 docking structures with the lowest energies tightly clustered to one another and having similar binding features (Figure $4 \mathrm{~A})$. The pyridine core, tolyl $\left(\mathrm{R}^{6}\right)$, 4-cyanophenyl $\left(\mathrm{R}^{5}\right)$ and piperidin-4-ylmethoxy $\left(R^{3}\right)$ group of these 20 structures are located in the same site or pocket in LSD1. Figures 4B and $4 \mathrm{C}$ show two views of the binding conformation of $\mathbf{1 7}$ with the lowest docking energy in the active site of LSD1. Its central pyridine ring is predicted to have favorable hydrophobic as well as electrostatic interactions with the flavin ring, Tyr761, Ala809, Thr810 and Ala539. The tolyl $\mathrm{R}^{6}$ group was found to be located in a mostly hydrophobic pocket surrounded by flavin, Phe538, Val333, Tyr761, Met332, Leu659, Lys661 and Trp695. The 4-cyanophenyl $\mathrm{R}^{5}$ group occupies a pocket surrounded by with Ala539, Phe538, Trp695, His564 and Thr335 and has favorable interactions with these residues. The protonated amine of the piperidin-4-ylmethoxy group was found to have a hydrogen bond as well as electrostatic interactions with the negatively charged sidechain of Asp555. In addition, the skeleton of the piperidin-4-ylmethoxy group possesses hydrophobic interactions with Ala809, Pro808, Ala539 and Asn540. 
Of interest is that the docking results could be used to rationalize our experimental SAR. For example, the predicted strong interactions between the protonated piperidin-4-ylmethoxy group and Asp555 (Figure 4B) could explain the importance of this group for LSD1 inhibition. As compared to compound $\mathbf{4 1}$ with a benzene core structure, possibly enhanced interactions between the pyridine core in $\mathbf{1 7}$ and flavin as well as Tyr761 (Figure 4B) could account for the increased activity of $\mathbf{1 7}$. For SAR on the $\mathrm{R}^{6}$ group, as compared to compound $\mathbf{5}$, the increased activity of $\mathbf{1 7}$ could be due to the favorable interactions of the methyl group in 17 with Phe538, Val333, Met332 and Lys661 (Figures 4B and C). In addition, the methyl is predicted to range from $\sim 3.3 \AA$ away from Met332 to $\sim 4.8 \AA$ from Trp695 by the docking study. This limited space might account for somewhat decreased activities of compounds $\mathbf{1 9}$ and $\mathbf{2 0}$ with a bigger -Et and -i-Pr group, respectively.

\section{Enzyme selectivity}

LSD1 belongs to a family of FAD-dependent monoamine oxidases including MAO-A and B. Due to an important role of MAO-A and -B in degradation of neurotransmitters in the central nervous system, selective inhibition of LSD1 is highly desirable. We investigated enzyme selectivity of several representative 3-(piperidin-4-ylmethoxy)pyridine containing LSD1 inhibitors against MAO-A and -B. Thus, compounds 5, 16, 17 and 22 were tested for their activity against recombinant human MAO-A and -B and their selectivity indices were also calculated. These results are summarized in Table 2. All of the four potent LSD1 inhibitors did not significantly inhibit MAO-A with $K_{\mathrm{i}}>50 \mu \mathrm{M}$, showing excellent selectivity. For MAO-B, compounds 5, $\mathbf{1 6}$ and $\mathbf{1 7}$ had only weak activities with $K_{\mathrm{i}}$ values of $9.7-18.7 \mu \mathrm{M}$. Due to its relatively low activity against LSD1, compound 5 showed 4.6× selectivity against MAO-B. However, potent LSD1 inhibitors 16 and 17 exhibited very high selectivity of $>160$ - and $>640$-folds against MAO-B, respectively. Moreover, despite having a relatively good activity against MAO-B $\left(K_{\mathrm{i}}=2.6 \mu \mathrm{M}\right)$, compound $\mathbf{2 2}$ is still a highly selective LSD1 inhibitor with a selectivity index of $>56$ against MAO-B, thanks to its potent inhibition of LSD1. Structurally, the $4-\mathrm{CF}_{3},-\mathrm{Me}$ and $-\mathrm{OCF}_{3}$ of the 6-phenyl ring in compounds 16, 17 and 22, respectively, account for the high selectivity against MAO-B, because as compared to the parent compound $\mathbf{5}$, these substituents have less impact $(<4 \times)$ on MAO-B inhibition, but increase the inhibitory potency against LSD1 by $>39$-folds.

Structurally similar 5,6-diaryl-3-(aminoalkyloxy)pyridine compounds were reported to be potent inhibitors of Akt kinase, ${ }^{41}$ which is also a drug target for cancer. We examined the enzyme selectivity of the most potent compound $\mathbf{1 7}$ against human Akt. Compound $\mathbf{1 7}$ was found to have a weak activity against Akt with an $\mathrm{IC}_{50}$ value of $87.6 \pm 21.6 \mu \mathrm{M}$, showing a high enzyme selectivity for LSD1. In addition, this chemo-type of compounds were reported as nicotinic receptor ligands ${ }^{42}$ as well as antituberculosis agents. ${ }^{43}$ Although these do not directly relate to the antitumor purpose of this study, a comprehensive enzyme selectivity profiling could be useful for future development of these compounds.

\section{Cell activity testing}

The most potent compound $\mathbf{1 7}$ was tested to see whether it can change the cellular H3K4 methylation level in a leukemia cell line MV4-11. Thus, cells were treated with 17 at 0.2 and $1 \mu \mathrm{M}$ and histones were then collected, separated by electrophoresis and probed by a 
specific antibody of $\mathrm{H} 3 \mathrm{~K} 4 \mathrm{me} 2$, as well as that of histone $\mathrm{H} 3$ as input controls. As can be seen in Figure 5, compound 17 appeared to increase the cellular level of H3K4me2 at $1 \mu \mathrm{M}$, suggesting it is cell membrane permeable and inhibits LSD1 in cells. It is noted because this method is semi-quantitative, more quantitative investigation could be useful to characterize how compound $\mathbf{1 7}$ affects cellular histone methylations globally and at specific gene loci.

Next, selected potent LSD1 inhibitors, including compound $\mathbf{S 2}$ (which is a cyclopropylamine-containing inhibitor, Figure S2) as a positive control, were tested for their ability to inhibit proliferation of four tumor cell lines and a normal fibroblast cell line WI-38. Among the four tumor cells, MV4-11 and Molm-13 are leukemia cell lines with an MLL gene translocation. Two representative breast cancer cells MCF-7 (estrogen receptor positive) and MDA-MB231 (estrogen receptor negative) were also included in the study, since LSD1 is often overexpressed in breast cancers. The results are summarized in Table 3, together with the LSD1 inhibitory activity of these compounds. Of interest is that the five competitive inhibitors exhibited strong antitumor activities against the 4 tumor cells with $\mathrm{EC}_{50}$ values of $280 \mathrm{nM}-8.6 \mu \mathrm{M}$. However, these compounds had weak or no activity against the growth of normal fibroblast cells WI-38. Particularly, LSD1 inhibitors 16, 17, 20 and 22 showed potent activity against proliferation of MV4-11 leukemia cells with $\mathrm{EC}_{50}$ values ranging from $280 \mathrm{nM}-480 \mathrm{nM}$, while less potent compound 13 exhibited a reduced activity $\left(\mathrm{EC}_{50}=1.1 \mu \mathrm{M}\right)$. These compounds were also found to have strong activity against the growth of Molm-13 leukemia cells with $\mathrm{EC}_{50}$ values of $0.84-4.4 \mu \mathrm{M}$. For MCF-7 breast cancer, more potent LSD1 inhibitors 16, 17, 20 and 22 appeared to be superior $\left(\mathrm{EC}_{50}: 3.3\right.$ $3.6 \mu \mathrm{M})$ to compound $\mathbf{1 3}\left(\mathrm{EC}_{50}: 6.9 \mu \mathrm{M}\right)$. These compounds also showed fairly good antiproliferative activity against MDA-MB231 breast cancer cells with $\mathrm{EC}_{50}$ values of 5.6 8.6 $\mu \mathrm{M}$. In addition, these five competitive LSD1 inhibitors showed similar antitumor activities as compared to the covalent inhibitor $\mathbf{S 2}$, which also exhibited strong antiproliferative activity $\left(\mathrm{EC}_{50}: 0.084-8.9 \mu \mathrm{M}\right)$ against the tumor cells, while it was inactive against the normal cells. Overall, the strong and selective antitumor activity suggested that this class of LSD1 inhibitors could be potentially useful cancer therapeutics and further efforts of compound development are therefore warranted.

\section{CONCLUSIONS}

LSD1 plays an important role in maintaining a balanced methylated H3K4, a key "histone code" for active gene transcription. It has also been found to be over-expressed in certain cancers such as breast cancer. ${ }^{28-30}$ Therefore, LSD1 represents a drug target for intervention and more chemo-types of potent LSD1 inhibitors are needed.

Based on previous SAR of cyclopropylamine containing LSD1 inhibitors, a series of 3(piperidin-4-ylmethoxy)pyridine and related compounds were found to be new LSD1 inhibitors. Structure guided molecular modeling and medicinal chemistry studies have led to the identification of several potent LSD1 inhibitors (e.g., 16, 17, 20 and 22) with $K_{\mathrm{i}}$ values as low as $29 \mathrm{nM}$. SAR investigation of this series of compounds showed that 1) a pyridine or pyrazine core structure is superior to a benzene ring; 2) a basic 3-(piperidin-4-ylmethoxy) $\mathrm{R}^{3}$ group is important to LSD1 inhibition; 3) 4-cyanophenyl group is the best $\mathrm{R}^{5}$ substituent in this study, while many other groups such as amide or alkyl-containing phenyl groups 
significantly reduce the inhibitory activity; 4 ) a phenyl $\mathrm{R}^{6}$ group is superior to a corresponding pyridine group; and 5) among the substituted phenyl $\mathrm{R}^{6}$ groups, several parasubstituents (e.g., - $\mathrm{Me}, \mathrm{CF}_{3}$ and $-\mathrm{OCF}_{3}$ in $\mathbf{1 7}, \mathbf{1 6}$ and $\mathbf{2 2}$ ) can significantly enhance LSD1 inhibition (by as high as 79×), while meta- or ortho-substituents are less effective.

Enzyme kinetics studies suggested that these compounds are competitive inhibitors against the dimethylated $\mathrm{H} 3 \mathrm{~K} 4$ peptide substrate. Consistent with the kinetics data, docking studies showed that these compounds can be well docked into the substrate binding site of LSD1. In addition, the docking results could be used to rationalize many of the observed SARs. Several representative LSD1 inhibitors were found to exhibit very high selectivity against related MAO-A and -B enzymes. This feature is desirable for this series of LSD1 inhibitors, due to important functions of MAO-A and -B in the central nervous system. The most potent LSD1 inhibitor 17 was found to increase the cellular level of H3K4me2, showing on-target activity in cells. However, it did not significantly affect the methylation levels of several other histone lysine residues (including $\mathrm{H} 3 \mathrm{~K} 4 \mathrm{me} 3$ ), presumably because these are not cellular substrates of LSD1. Finally, five potent LSD1 inhibitors were found to exhibit potent to good activity against proliferation of two MLL-rearranged leukemia cells and two breast cancer cells with $\mathrm{EC}_{50}$ values ranging from $0.28-8.6 \mu \mathrm{M}$, while no or very weak activity of these compounds against the growth of normal fibroblast cells were observed.

\section{Experimental Section}

All chemicals for synthesis were purchased from Alfa Aesar (Ward Hill, MA) or Aldrich (Milwaukee, WI). All compounds were characterized by ${ }^{1} \mathrm{H}$ NMR on a Varian (Palo Alto, CA) 400-MR spectrometer. Identify of the most active compounds was confirmed by HRMS using an Agilent 6550 iFunnel quadrupole-time-of-flight (Q-TOF) mass spectrometer with electrospray ionization (ESI). The purities of synthesized compounds were determined by a Shimadzu Prominence HPLC with a Zorbax C18 column $(4.6 \times 250 \mathrm{~mm})$ monitored by UV at $254 \mathrm{~nm}$. The purities of the reported compounds were found to be $>95 \%$. HPLC-MS experiments were performed using a Shimadzu Prominence HPLC connected to a LCMS-2020 MS system.

Synthesis and characterization of compounds 4-45 can be found in Supporting Information Experimental Section.

\section{LSD1 inhibition}

The catalytic domain (172-833) of human LSD1 was cloned, inserted into pGEX-KG vector and the DNA sequence was verified by sequencing. The pGEX-KG-LSD1 plasmid thus generated was transformed into E. coli BL21-CodonPlus strain (Agilent) and cultured at $37^{\circ} \mathrm{C}$ in LB medium containing ampicillin $(50 \mu \mathrm{g} / \mathrm{mL})$ and chloramphenicol $(34 \mu \mathrm{g} / \mathrm{mL})$. When the optical density of the bacterial culture approached $\sim 0.9$ at $600 \mathrm{~nm}, \mathrm{LSD} 1$ expression was induced by adding $0.2 \mathrm{mM}$ isopropylthiogalactoside (IPTG) at $25^{\circ} \mathrm{C}$ for 20 hours. Cells were next collected, lysed, centrifuged for $20 \mathrm{~min}$ at 20,000 rpm. The resulting supernatant was subjected to an affinity column chromatography with glutathione sepharose resins. The recombinant GST-LSD1 fusion protein was obtained in $~ 90 \%$ purity (SDS- 
PAGE) by elution with $10 \mathrm{mM}$ of glutathione solution and a secondary purification using a Superdex 200 gel filtration column chromatography followed by concentration.

A mass spectrometry based biochemical assay for LSD1 was developed, with the amount of demethylated product peptide being quantitatively determined by HPLC-MS. Increasing concentrations of a compound were incubated with LSD1 $(150 \mathrm{nM})$ in $50 \mathrm{mM}$ phosphate buffer ( $\mathrm{pH}=7.0$ ) containing $0.01 \%$ Brij- 35 for $10 \mathrm{~min}$ at $25^{\circ} \mathrm{C}$, before initiation of the reaction by adding $10 \mu \mathrm{M}$ of dimethylated peptide substrate

ARTK(Me2)QTARKSTGGKAPRKQKA. The total volume of the reaction mixture was 60 $\mu \mathrm{L}$. Reactions were terminated after $30 \mathrm{~min}$ by adding $6 \mathrm{~N}$ formic acid $(5 \mu \mathrm{L})$ and $20 \mu \mathrm{L}$ of the reaction mixture was subjected to HPLC-MS to separate and determine the amount of the reaction product. HPLC was run using a Phenomenex C18 column $(250 \times 4.6 \mathrm{~mm}, 5 \mu \mathrm{m})$ with acetonitrile:water (40:60, containing $0.1 \%$ TFA) as an eluent at a flow rate of $0.5 \mathrm{~mL} /$ min. A selected ion monitoring (SIM) for 1142 Da was used to detect and quantitate the amount of the product ARTK(Me1)QTARKSTGGKAPRKQKA (parameters: Interface Voltage, $3.0 \mathrm{kV}$; Detector Voltage, $1.3 \mathrm{kV}$; Nebulizing Gas, $1.5 \mathrm{~L} / \mathrm{min}$; Drying Gas, $15 \mathrm{~L} /$ min; Desolvation Line Temperature, $300{ }^{\circ} \mathrm{C}$; Heat Block Temperature, $300^{\circ} \mathrm{C}$; Pirani Gauge Vacuum, $150 \mathrm{~Pa}$; Ion Gauge Vacuum: 5e-4 Pa). To ensure an initial velocity was determined, $\sim 5 \%$ of the dimethylated substrate was consumed before the reaction was stopped.

Therefore, monomethylated peptide was obtained almost as the only product. No significant amount of the non-methylated product was detected.

Data were imported into Prism 5.0 (Graphpad) and the $\mathrm{IC}_{50}$ values were determined using the sigmoidal dose response fitting in the program. For compounds with $\mathrm{IC}_{50} \mathrm{~s}>1.5 \mu \mathrm{M}$ (i.e., > [LSD1]), $K_{\mathrm{i}}$ values were calculated using the Cheng-Prusoff equation $K_{\mathrm{i}}=\mathrm{IC}_{50} /(1+$ $\left.[\mathrm{S}] / K_{\mathrm{m}}\right)$, where [S] is the concentration of the peptide substrate $(10 \mu \mathrm{M})$ and $K_{\mathrm{m}}$ is a reported value of $10 \mu \mathrm{M} .{ }^{27 \mathrm{a}}$ For compounds with $\mathrm{IC}_{50} \mathrm{~s}<1.5 \mu \mathrm{M}, K_{\mathrm{i}}$ values were calculated using the Morrison tight inhibition modeling in Prism. The reported $K_{\mathrm{i}}$ values were the mean values of at least three independent experiments.

\section{Enzyme kinetics study}

A steady-state kinetics study was conducted by measuring the initial velocities of reactions catalyzed by LSD1 while varying the concentrations of compound $5(0,2 \mu \mathrm{M}, 4 \mu \mathrm{M}$ and 6 $\mu \mathrm{M})$ and the peptide substrate $(2 \mu \mathrm{M}, 3 \mu \mathrm{M}, 5 \mu \mathrm{M}, 10 \mu \mathrm{M}, 50 \mu \mathrm{M}$ and $100 \mu \mathrm{M})$. Data were imported into SigmaPlot and fitted into the competitive, noncompetitive and uncompetitive inhibition models. The best kinetic model was determined by the highest $\mathrm{R}^{2}$ and lowest AICc values. Lineweaver-Burk plots were generated by Sigmaplot.

\section{Molecular modeling}

Docking studies were performed with our previous published methods ${ }^{44-46}$ using Schrödinger suite (version 2015) ${ }^{40}$ which includes all of the programs described below. The crystal structure of LSD1 in complex with an H3K4 peptide (PDB: 2V1D) was prepared using the module "protein preparation wizard" in Maestro (version 10.1) using the default protein parameters. Hydrogen atoms were added, the H3K4 peptide ligand and all water molecules were extracted, and FAD was retained in the protein structure for docking. $\mathrm{H}$ - 
bonds were next optimized, the partial charges for all atoms were assigned, and the protein was energy-minimized using OPLS-2005 force field. A receptor grid, which is large enough to contain the active site, was generated with the program Glide without any constraints. Inhibitor compounds were built, energy-minimized using OPLS-2005 force field in Maestro and then docked into the prepared protein structure using Glide (docking parameters: standard-precision and dock flexibly).

\section{Inhibition of MAO-A/-B}

Human recombinant MAO-A and -B enzymes were purchased from Sigma and their biochemical activity as well as inhibition were determined using a MAO-Glo assay kit from Promega. Following the manufacturer's protocol, the assays were performed in 384-well white plates by adding all reagents in the kit, MAO-A or -B $(100 \mathrm{nM})$ and increasing concentrations of inhibitors to a final volume of $20 \mu \mathrm{L}$. After $60 \mathrm{~min}$, the reactions were stopped by adding a reconstituted luciferin detection reagent ( $20 \mu \mathrm{L} /$ well). Upon incubation for an additional $20 \mathrm{~min}$, luminescence of each well was determined using a Beckman DTX-880 microplate reader. Using $K_{\mathrm{m}}$ values provided in the kit, $K_{\mathrm{i}}$ values were similarly calculated as described above.

\section{Inhibition of Akt kinase}

The inhibitory activity of compound $\mathbf{1 7}$ against human recombinant Akt kinase was determined using a commercially available ELISA kit (Enzo life Sciences, Farmingdale, $\mathrm{NY}$ ). Following the manufacturer's protocol, Akt kinase ( $5 \mathrm{nM})$, ATP and increasing concentrations of $17(0.01-100 \mu \mathrm{M})$ were added to a final volume of $30 \mu \mathrm{L}$ in a 96 -well plate pre-coated with a substrate. After 60 mins incubation in $30^{\circ} \mathrm{C}$, the reactions were stopped by removal of all reactants. The primary antibody against the phosphorylated substrate and a peroxidase conjugated secondary antibody were added sequentially. The optical absorbance at $450 \mathrm{nM}$ of each well was developed with tetramethylbenzidine substrate (TMB) and determined using a Beckman DTX-880 microplate reader. The data were imported into Prism (version 5.0, GraphPad) and $\mathrm{IC}_{50}$ s were calculated by using a standard dose response curve fitting. The reported value is the average of three independent experiments.

\section{Western blot}

$10^{6} \mathrm{MV} 4-11$ cells/well were incubated compounds $\mathbf{1 7}$ and $\mathbf{2 8}$ at 0.2 and $1 \mu \mathrm{M}$ for 3 days. Histone proteins were extracted using EpiQuik ${ }^{\mathrm{TM}}$ total histone extraction kit (Epigentek), according to the manufacturer's protocol. Equal amounts of histones $(2 \mu \mathrm{g})$ were separated on SDS-PAGE and transferred to PVDF membranes. The blots were probed with primary antibodies against H3K4me2 and me3, H3K27me2, H3K36me2, H4K20me2 and H3 (Cell Signaling), followed by anti-rabbit IgG (Thermo Scientific) secondary antibodies. Quantitation of these blots were performed using the program ImageJ.

\section{Cell growth inhibition}

The anti-proliferation assays were done using our previous method. ${ }^{47,48}$ In brief, for leukemia cells, $10^{6}$ cells per well were added into 96-well plates and cultured with 
increasing concentrations of a compound in RPMI-1640 medium supplemented with $10 \%$ fetal bovine serum and penicillin $(100 \mathrm{U} / \mathrm{mL})$ and streptomycin $(100 \mu \mathrm{g} / \mathrm{mL})$ at $37^{\circ} \mathrm{C}$ in a $5 \% \mathrm{CO}_{2}$ atmosphere with $100 \%$ humidity. For solid tumor and normal cells, $10^{5}$ cells per well were added into 96-well plates and cultured in Dulbecco's Modified Eagle's Medium (DMEM) supplemented with $10 \%$ fetal bovine serum and penicillin $(100 \mathrm{U} / \mathrm{mL})$ and streptomycin $(100 \mu \mathrm{g} / \mathrm{mL})$ overnight for cell attachment. After addition of increasing concentration of a compound, plates were incubated for a given period of time. Cell viability was assessed by using an XTT assay kit (Roche) for leukemia cells or an MTT assay (Sigma) for attachment cells. Compound $\mathrm{IC}_{50}$ values were calculated from dose response curves using Prism 5.0.

\section{Supplementary Material}

Refer to Web version on PubMed Central for supplementary material.

\section{Acknowledgment}

This work was supported by a grant (RP150129) from Cancer Prevention and Research Institute of Texas (CPRIT) and a grant (R01NS080963) from National Institute of Neurological Disorders and Stroke (NINDS/NIH) to Y.S. We also thank Dr. Feng Li in BCM Metabolomics Core for performing HRMS.

\section{ABBREVATIONS}

$\begin{array}{ll}\text { BOC } & \begin{array}{l}\text { tert-butyloxycarbonyl } \\ \text { FAD }\end{array} \\ \text { H3K4 } & \text { Histone H3 lysine4 } \\ \text { H3K4me1 } & 2 \text { or 3, mono-, di-, or tri-methylated H3K4 } \\ \text { LSD1 } & \text { lysine specific demethylase 1 } \\ \text { MAO } & \text { monoamine oxidase } \\ \text { MLL } & \text { mixed lineage leukemia } \\ \text { SAR } & \text { structure activity relationship }\end{array}$

\section{References and Notes}

1. For a recent review, see. Kouzarides T. Chromatin modifications and their function. Cell. 2007; 128:693-705. [PubMed: 17320507]

2. Jones PA, Baylin SB. The epigenomics of cancer. Cell. 2007; 128:683-692. [PubMed: 17320506]

3. Wilson CB, Rowell E, Sekimata M. Epigenetic control of T-helper-cell differentiation. Nat. Rev. Immunol. 2009; 9:91-105. [PubMed: 19151746]

4. Tsankova N, Renthal W, Kumar A, Nestler EJ. Epigenetic regulation in psychiatric disorders. Nat. Rev. Neurosci. 2007; 8:355-367. [PubMed: 17453016]

5. Copeland RA, Solomon ME, Richon VM. Protein methyltransferases as a target class for drug discovery. Nat. Rev. Drug Discov. 2009; 8:724-732. [PubMed: 19721445]

6. Cole PA. Chemical probes for histone-modifying enzymes. Nat. Chem. Biol. 2008; 4:590-597. [PubMed: 18800048]

7. Falkenberg KJ, Johnstone RW. Histone deacetylases and their inhibitors in cancer, neurological diseases and immune disorders. Nat. Rev. Drug Discov. 2014; 9:673-691. [PubMed: 25131830] 
8. Milne TA, Briggs SD, Brock HW, Martin ME, Gibbs D, Allis CD, Hess JL. MLL targets SET domain methyltransferase activity to Hox gene promoters. Mol. Cell. 2002; 10:1107-1117. [PubMed: 12453418]

9. Briggs SD, Bryk M, Strahl BD, Cheung WL, Davie JK, Dent SY, Winston F, Allis CD. Histone H3 lysine 4 methylation is mediated by Set1 and required for cell growth and rDNA silencing in Saccharomyces cerevisiae. Genes Dev. 2001; 15:3286-3295. [PubMed: 11751634]

10. Milne TA, Briggs SD, Brock HW, Martin ME, Gibbs D, Allis CD, Hess JL. MLL targets SET domain methyltransferase activity to Hox gene promoters. Mol. Cell. 2002; 10:1107-1117. [PubMed: 12453418]

11. Krivtsov AV, Armstrong SA. MLL translocations, histone modifications and leukaemia stem-cell development. Nat. Rev. Cancer. 2007; 7:823-833. [PubMed: 17957188]

12. Nakamura T, Mori T, Tada S, Krajewski W, Rozovskaia T, Wassell R, Dubois G, Mazo A, Croce CM, Canaani E. ALL-1 is a histone methyltransferase that assembles a supercomplex of proteins involved in transcriptional regulation. Mol. Cell. 2002; 10:1119-1128. [PubMed: 12453419]

13. Shi Y, Lan F, Matson C, Mulligan P, Whetstine JR, Cole PA, Casero RA. Histone demethylation mediated by the nuclear amine oxidase homolog LSD1. Cell. 2004; 119:941-953. [PubMed: 15620353]

14. Kerenyi MA, Shao Z, Hsu YJ, Guo G, Luc S, O'Brien K, Fujiwara Y, Peng C, Nguyen M, Orkin $\mathrm{SH}$. Histone demethylase Lsd1 represses hematopoietic stem and progenitor cell signatures during blood cell maturation. Elife. 2013; 2:e00633. [PubMed: 23795291]

15. Metzger E, Wissmann M, Yin N, Müller JM, Schneider R, Peters AH, Günther T, Buettner R, Schüle R. LSD1 demethylates repressive histone marks to promote androgen-receptor-dependent transcription. Nature. 2005; 437:436-439. [PubMed: 16079795]

16. Wang J, Hevi S, Kurash JK, Lei H, Gay F, Bajko J, Su H, Sun W, Chang H, Xu G, Gaudet F, Li E, Chen T. The lysine demethylase LSD1 (KDM1) is required for maintenance of global DNA methylation. Nat. Genet. 2009; 41:125-129. [PubMed: 19098913]

17. Chen CS, Sorensen PH, Domer PH, Reaman GH, Korsmeyer SJ, Heerema NA, Hammond GD, Kersey JH. Molecular rearrangements on chromosome 11q23 predominate in infant acute lymphoblastic leukemia and are associated with specific biologic variables and poor outcome. Blood. 1993; 81:2386-2393. [PubMed: 8481519]

18. Mrozek K, Heinonen K, Lawrence D, Carroll AJ, Koduru PR, Rao KW, Strout MP, Hutchison RE, Moore JO, Mayer RJ, Schiffer CA, Bloomfield CD. Adult patients with de novo acute myeloid leukemia and $\mathrm{t}(9 ; 11)(\mathrm{p} 22 ; \mathrm{q} 23)$ have a superior outcome to patients with other translocations involving band 11q23: a cancer and leukemia group B study. Blood. 1997; 90:4532-4538. [PubMed: 9373264]

19. Hilden JM, Dinndorf PA, Meerbaum SO, Sather H, Villaluna D, Heerema NA, McGlennen R, Smith FO, Woods WG, Salzer WL, Johnstone HS, Dreyer Z, Reaman GH. Analysis of prognostic factors of acute lymphoblastic leukemia in infants: report on CCG 1953 from the Children's Oncology Group. Blood. 2006; 108:441-451. [PubMed: 16556894]

20. Okada Y, Feng Q, Lin Y, Jiang Q, Li Y, Coffield VM, Su L, Xu G, Zhang Y. hDOT1L links histone methylation to leukemogenesis. Cell. 2005; 121:167-178. [PubMed: 15851025]

21. Bitoun E, Oliver PL, Davies KE. The mixed-lineage leukemia fusion partner AF4 stimulates RNA polymerase II transcriptional elongation and mediates coordinated chromatin remodeling. Hum. Mol. Genet. 2007; 16:92-106. [PubMed: 17135274]

22. Krivtsov AV, Feng Z, Lemieux ME, Faber J, Vempati S, Sinha AU, Xia X, Jesneck J, Bracken AP, Silverman LB, Kutok JL, Kung AL, Armstrong SA. H3K79 methylation profiles define murine and human MLL-AF4 leukemias. Cancer Cell. 2008; 14:355-368. [PubMed: 18977325]

23. For work from us, see Yao Y, Chen P, Diao J, Cheng G, Deng L, Anglin JL, Prasad BV, Song Y. Selective inhibitors of histone methyltransferase DOT1L: design, synthesis, and crystallographic studies. J. Am. Chem. Soc. 2011; 133:16746-16749. [PubMed: 21936531] Anglin JL, Deng L, Yao Y, Cai G, Liu Z, Jiang H, Cheng G, Chen P, Dong S, Song Y. Synthesis and structure-activity relationship investigation of adenosine-containing inhibitors of histone methyltransferase DOT1L. J. Med. Chem. 2012; 55:8066-8074. [PubMed: 22924785] Deng L, Zhang L, Yao Y, Wang C, Redell MS, Dong S, Song Y. Synthesis, activity and metabolic stability of non-ribose containing inhibitors of histone methyltransferase DOT1L. Med. Chem. Commun. 2013; 4:822-826. Liu W, 
Deng L, Song Y, Redell M. DOT1L Inhibition Sensitizes MLL-Rearranged AML to Chemotherapy. PLoS One. 2014; 9:e98270. [PubMed: 24858818]

24. For work from other groups, see Daigle SR, Olhava EJ, Therkelsen CA, Majer CR, Sneeringer CJ, Song J, Johnston LD, Scott MP, Smith JJ, Xiao Y, Jin L, Kuntz KW, Chesworth R, Moyer MP, Bernt KM, Tseng JC, Kung AL, Armstrong SA, Copeland RA, Richon VM, Pollock RM. Selective killing of mixed lineage leukemia cells by a potent small-molecule DOT1L inhibitor. Cancer Cell. 2011; 20:53-65. [PubMed: 21741596] Basavapathruni A, Jin L, Daigle SR, Majer CR, Therkelsen CA, Wigle TJ, Kuntz KW, Chesworth R, Pollock RM, Scott MP, Moyer MP, Richon VM, Copeland RA, Olhava EJ. Conformational adaptation drives potent, selective and durable inhibition of the human protein methyltransferase DOT1L. Chem. Biol. Drug Des. 2012; 80:971-980. [PubMed: 22978415] Yu W, Chory EJ, Wernimont AK, Tempel W, Scopton A, Federation A, Marineau JJ, Qi J, Barsyte-Lovejoy D, Yi J, Marcellus R, Iacob RE, Engen JR, Griffin C, Aman A, Wienholds E, Li F, Pineda J, Estiu G, Shatseva T, Hajian T, Al-Awar R, Dick JE, Vedadi M, Brown PJ, Arrowsmith CH, Bradner JE, Schapira M. Catalytic site remodelling of the DOT1L methyltransferase by selective inhibitors. Nat. Commun. 2012; 3:1288. [PubMed: 23250418] Daigle SR, Olhava EJ, Therkelsen CA, Basavapathruni A, Jin L, Boriack-Sjodin PA, Allain CJ, Klaus CR, Raimondi A, Scott MP, Waters NJ, Chesworth R, Moyer MP, Copeland RA, Richon VM, Pollock RM. Potent inhibition of DOT1L as treatment for MLL-fusion leukemia. Blood. 2013; 122:1017-1025. [PubMed: 23801631]

25. Binda C, Valente S, Romanenghi M, Pilotto S, Cirilli R, Karytinos A, Ciossani G, Botrugno OA, Forneris F, Tardugno M, Edmondson DE, Minucci S, Mattevi A, Mai A. Biochemical, structural, and biological evaluation of tranylcypromine derivatives as inhibitors of histone demethylases LSD1 and LSD2. J. Am. Chem. Soc. 2010; 132:6827-6833. [PubMed: 20415477]

26. See recent reviews and the references therein. a Suzuki T, Miyata N. Lysine demethylases inhibitors. J. Med. Chem. 2011; 54:8236-8250. [PubMed: 21955276] b Mould DP, McGonagle AE, Wiseman DH, Williams EL, Jordan AM. Reversible inhibitors of LSD1 as therapeutic agents in acute myeloid leukemia: clinical significance and progress to date. Med. Res. Rev. 2015; 35:586-618. [PubMed: 25418875]

27. For more recent LSD1 inhibitors, see Neelamegam R, Ricq EL, Malvaez M, Patnaik D, Norton S, Carlin SM, Hill IT, Wood MA, Haggarty SJ, Hooker JM. Brain-penetrant LSD1 inhibitors can block memory consolidation. ACS Chem. Neurosci. 2012; 3:120-128. [PubMed: 22754608] Zheng YC, Duan YC, Ma JL, Xu RM, Zi X, Lv WL, Wang MM, Ye XW, Zhu S, Mobley D, Zhu YY, Wang JW, Li JF, Wang ZR, Zhao W, Liu HM. Triazole-dithiocarbamate based selective lysine specific demethylase 1 (LSD1) inactivators inhibit gastric cancer cell growth, invasion, and migration. J. Med. Chem. 2013; 56:8543-8560. [PubMed: 24131029] Sorna V, Theisen ER, Stephens B, Warner SL, Bearss DJ, Vankayalapati H, Sharma S. High-throughput virtual screening identifies novel N'-(1-phenylethylidene)-benzohydrazides as potent, specific, and reversible LSD1 inhibitors. J. Med. Chem. 2013; 56:9496-9508. [PubMed: 24237195] Prusevich P, Kalin JH, Ming SA, Basso M, Givens J, Li X, Hu J, Taylor MS, Cieniewicz AM, Hsiao PY, Huang R, Roberson H, Adejola N, Avery LB, Casero RA Jr. Taverna SD, Qian J, Tackett AJ, Ratan RR, McDonald OG, Feinberg AP, Cole PA. A Selective Phenelzine Analogue Inhibitor of Histone Demethylase LSD1. ACS Chem. Biol. 2014; 9:1284-1293. [PubMed: 24707965] Huang Y, Greene E, Stewart TM, Goodwin AC, Baylin SB, Woster PM, Casero RA. Inhibition of lysine-specific demethylase 1 by polyamine analogues results in reexpression of aberrantly silenced genes. PNAS. 2007; 104:80238028. [PubMed: 17463086] Huang Y, Stewart TM, Wu Y, Baylin SB, Marton LJ, Perkins B, Jones RJ, Woster PM, Casero RA Jr. Novel oligoamine analogues inhibit lysine-specific demethylase 1 and induce reexpression of epigenetically silenced genes. Clin. Cancer Res. 2009; 15:7217-7228. [PubMed: 19934284] Sharma SK, Wu Y, Steinbergs N, Crowley ML, Hanson AS, Casero RA Jr. Woster PM. (Bis)urea and (Bis)thiourea Inhibitors of Lysine-Specific Demethylase 1 as Epigenetic Modulators. J. Med. Chem. 2010; 53:5197-5212. [PubMed: 20568780] Kutz CJ, Holshouser SL, Marrow EA, Woster PM. 3,5-Diamino-1,2,4-triazoles as a novel scaffold for potent, reversible LSD1 (KDM1A) inhibitors. MedChemComm. 2014; 5:1863-1870. [PubMed: 25580204] Hitchin JR, Blagg J, Burke R, Burns S, Cockerill MJ, Fairweather EE, Hutton C, Jordan AM, McAndrew C, Mirza A, Mould D, Thomson GT, Waddell I, Ogilvie DJ. Development and evaluation of selective, reversible LSD1 inhibitors derived from fragments. Med. Chem. Comm. 2014; 4:15131522. Culhane JC, Wang D, Yen PM, Cole PA. Comparative analysis of small molecules and 
histone substrate analogues as LSD1 lysine demethylase inhibitors. J. Am. Chem. Soc. 2010; 132:3164-3176. [PubMed: 20148560]

28. Kahl P, Gullotti L, Heukamp LC, Wolf S, Friedrichs N, Vorreuther R, Solleder G, Bastian PJ, Ellinger J, Metzger E, Schule R, Buettner R. Androgen receptor coactivators lysine-specific histone demethylase 1 and four and a half LIM domain protein 2 predict risk of prostate cancer recurrence. Cancer Res. 2006; 66:11341-11347. [PubMed: 17145880]

29. Schulte JH, Lim S, Schramm A, Friedrichs N, Koster J, Versteeg R, Ora I, Pajtler K, Klein-Hitpass L, Kuhfittig-Kulle S, Metzger E, Schule R, Eggert A, Buettner R, Kirfel J. Lysine-specific demethylase 1 is strongly expressed in poorly differentiated neuroblastoma: implications for therapy. Cancer Res. 2009; 69:2065-2071. [PubMed: 19223552]

30. Lim S, Janzer A, Becker A, Zimmer A, Schule R, Buettner R, Kirfel J. Lysine-specific demethylase 1 (LSD1) is highly expressed in ER-negative breast cancers and a biomarker predicting aggressive biology. Carcinogenesis. 2010; 31:512-520. [PubMed: 20042638]

31. Harris WJ, Huang X, Lynch JT, Spencer GJ, Hitchin JR, Li Y, Ciceri F, Blaser JG, Greystoke BF, Jordan AM, Miller CJ, Ogilvie DJ, Somervaille TC. The histone demethylase KDM1A sustains the oncogenic potential of MLL-AF9 leukemia stem cells. Cancer Cell. 2012; 21:473-487. [PubMed: 22464800]

32. Dent SY, Chandra J. The lasting influence of LSD1 in the blood. Elife. 2013; 2:e00963. [PubMed: 23795303]

33. Lynch JT, Harris WJ, Somervaille TC. LSD1 inhibition: a therapeutic strategy in cancer? Expert Opin. Ther. Targets. 2012; 16:1239-1249.

34. Dhanak, D. Drugging the Cancer Epigenome. Proceedings of the 104th Annual Meeting of the American Association for Cancer Research; Washington, DC, Philadelphia, PA. 2013 April 6-10; AACR;

35. Khan MN, Suzuki T, Miyata N. An overview of phenylcyclopropylamine derivatives: biochemical and biological significance and recent developments. Med. Res. Rev. 2013; 33:873-910. [PubMed: 22893613]

36. Mimasu S, Umezawa N, Sato S, Higuchi T, Umehara T, Yokoyama S. Structurally designed trans-2-phenylcyclopropylamine derivatives potently inhibit histone demethylase LSD1/KDM1. Biochemistry. 2010; 49:6494-6503. [PubMed: 20568732]

37. Tortorici M, Borrello MT, Tardugno M, Chiarelli LR, Pilotto S, Ciossani G, Vellore NA, Bailey SG, Cowan J, O'Connell M, Crabb SJ, Packham G, Mai A, Baron R, Ganesan A, Mattevi A. Protein recognition by short peptide reversible inhibitors of the chromatin-modifying LSD1/ CoREST lysine demethylase. ACS Chem Biol. 2013; 8:1677-1682. [PubMed: 23721412]

38. Stavropoulos P, Blobel G, Hoelz A. Crystal structure and mechanism of human lysine-specific demethylase-1. Nat. Struct. Mol. Biol. 2006; 13:626-632. [PubMed: 16799558]

39. Forneris F, Binda C, Adamo A, Battaglioli E, Mattevi A. Structural basis of LSD1-CoREST selectivity in histone H3 recognition. J. Biol. Chem. 2007; 282:20070-20074. [PubMed: 17537733]

40. Schrödinger Suite, version 2015. Schrödinger, LLC; New York, NY: 2015.

41. Lin H, Yamashita DS, Zeng J, Xie R, Wang W, Nidarmarthy S, Luengo JI, Rhodes N, Knick VB, Choudhry AE, Lai Z, Minthorn EA, Strum SL, Wood ER, Elkins PA, Concha NO, Heerding DA. 2,3,5-Trisubstituted pyridines as selective AKT inhibitors-Part I: Substitution at 2-position of the core pyridine for ROCK1 selectivity. Bioorg. Med. Chem. Lett. 2010; 20:673-678. [PubMed: 20006497]

42. Lin, N-H.; He, Y.; Holladay, MW.; Ryther, K.; Li, Y. 3-pyridyloxymethyl heterocyclic ether compounds useful in controlling chemical synaptic transmission.. 1997. US patent 5,629,325

43. Ballell L, Bates RH, Young RJ, Alvarez-Gomez D, Alvarez-Ruiz E, Barroso V, Blanco D, Crespo B, Escribano J, González R, Lozano S, Huss S, Santos-Villarejo A, Martín-Plaza JJ, Mendoza A, Rebollo-Lopez MJ, Remuiñan-Blanco M, Lavandera JL, Pérez-Herran E, Gamo-Benito FJ, García-Bustos JF, Barros D, Castro JP, Cammack N. Fueling open-source drug discovery: 177 small-molecule leads against tuberculosis. ChemMedChem. 2013; 8:313-321. [PubMed: 23307663] 
44. Zheng B, Yao Y, Liu Z, Deng L, Anglin JL, Jiang H, Prasad BVV, Song Y. Crystallographic Investigation and Selective Inhibition of Mutant Isocitrate Dehydrogenase. ACS Med. Chem. Lett. 2013; 4:542-546. [PubMed: 23795241]

45. Deng L, Diao J, Chen P, Pujari V, Yao Y, Cheng G, Crick DC, Prasad BVV, Song Y. Inhibition of 1-Deoxy-D-Xylulose-5-Phosphate Reductoisomerase by Lipophilic Phosphonates: SAR, QSAR and Crystallographic Studies. J. Med. Chem. 2011; 54:4721-34. [PubMed: 21561155]

46. Deng L, Sundriyal S, Rubio V, Shi Z, Song Y. Coordination Chemistry Based Approach to Lipophilic Inhibitors of 1-Deoxy-D-xylulose-5-phosphate Reductoisomerase. J. Med. Chem. 2009; 52:6539-42. [PubMed: 19888756]

47. Zhang L, Deng L, Chen F, Yao Y, Wu B, Wei L, Mo Q, Song Y. Inhibition of Histone H3K79 Methylation Selectively Inhibits Proliferation, Self-renewal and Metastatic Potential of Breast Cancer. Oncotarget. 2014; 5:10665-10677. [PubMed: 25359765]

48. Liu Z, Yao Y, Kogiso M, Zheng B, Deng L, Qiu JJ, Dong S, Lv H, Gallo JM, Li X-N, Song Y. Inhibition of Cancer-Associated Mutant Isocitrate Dehydrogenases: Synthesis, SAR and Selective Antitumor Activity. J. Med. Chem. 2014; 57:8307-8318. [PubMed: 25271760] 
A
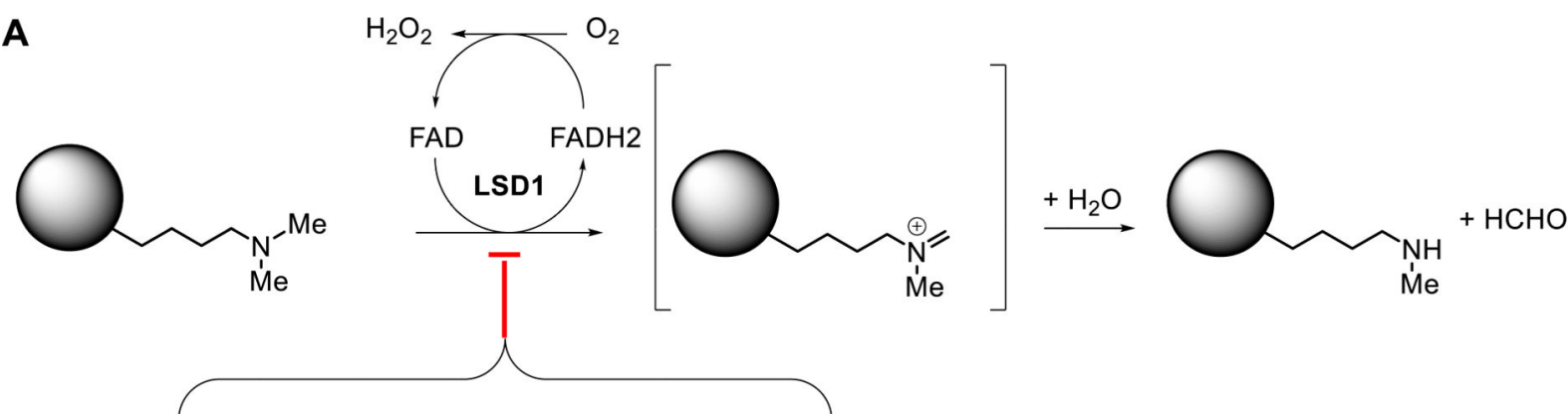

B

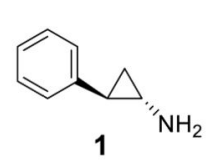

Tranylcypromine

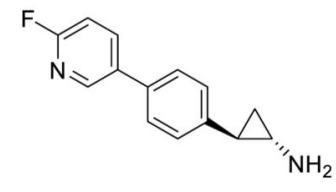<smiles>CN1CCN(C(=O)CNC2CC2c2ccc(OCc3ccccc3)cc2)CC1</smiles><smiles>NNCc1ccccc1</smiles><smiles>C#CCN(C)Cc1ccccc1</smiles><smiles>Cc1ccc(Cn2cc(CSC(=O)N3CCN(C(=O)O)CC3)nn2)cc1</smiles>

Figure 1.

(A) Mechanism of catalysis for LSD1; (B) Structures of representative LSD1 inhibitors, among which compounds in the upper panel are irreversible inhibitors and those in the lower panel are reversible. 


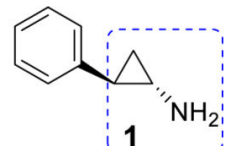

$\mathrm{IC}_{50}$ for LSD1: $15.7 \mu \mathrm{M}$ MAO-A: $0.29 \mu \mathrm{M}$ MAO-B: $0.078 \mu \mathrm{M}$

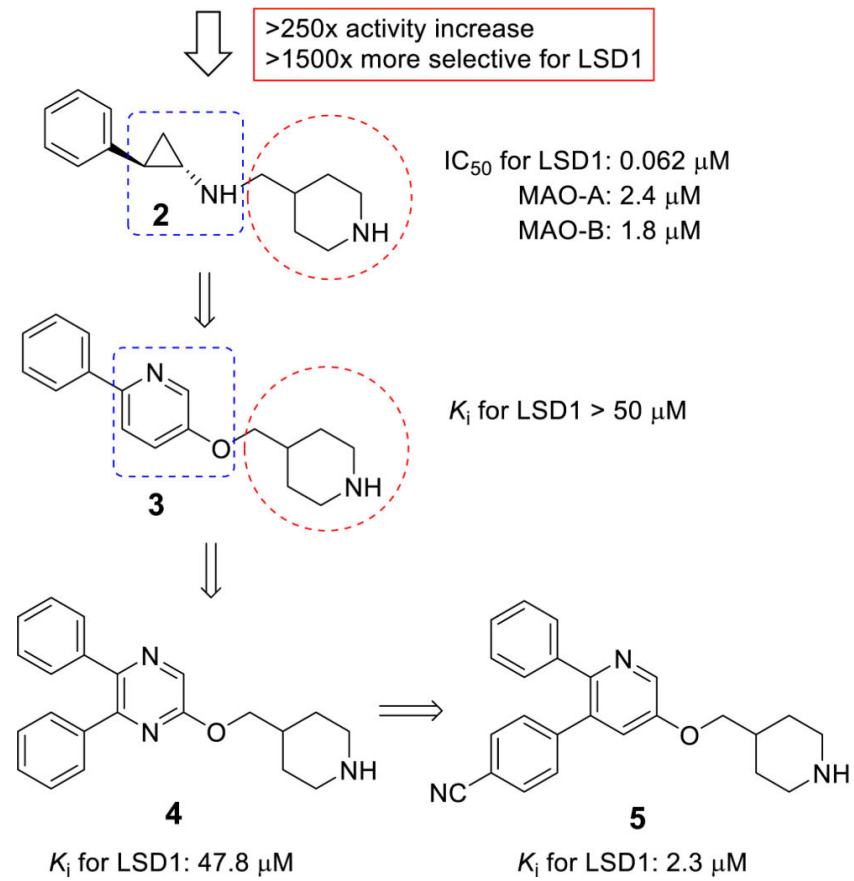

Chart 1.

Inhibitor design leading to the finding of new LSD1 inhibitors. $\mathrm{IC}_{50}$ values of compound $\mathbf{1}$ against MAO-A and -B are from Ref. 35. 


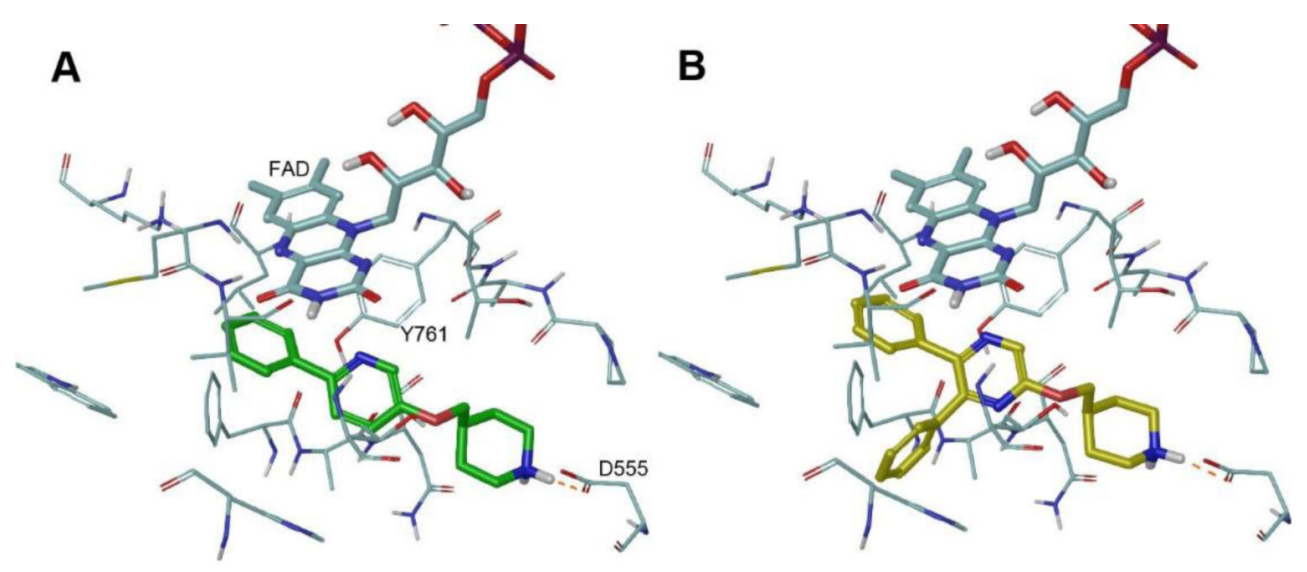

Figure 2.

Docking studies of potential LSD1 inhibitors, using an LSD1 crystal structure (PDB: 2V1D) as the docking template. For clarity, only key residues (in light blue) in the active site of LSD1 are shown, together with the cofactor FAD (light blue tube model). Hydrogen bonds are shown as orange dashed lines. (A) The lowest-energy docking structure of compound $\mathbf{3}$ (tube model with $\mathrm{C}$ atoms in green), suggesting favorable interactions between its pyridine ring and FAD and Y761; (B) The lowest-energy docking structure of 4 (in yellow), showing introducing an additional 5-phenyl group could be favorable. 
<smiles>[R]c1ccc(C(=O)C(=O)c2ccc([R])cc2)cc1</smiles>

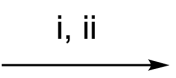<smiles>[R]c1ccc(-c2ncc(Cl)nc2-c2ccc([R])cc2)cc1</smiles><smiles>[R]c1ccc(-c2ncc(OCC3CCN(C(=O)OC(C)(C)C)CC3)nc2-c2ccc([R])cc2)cc1</smiles>

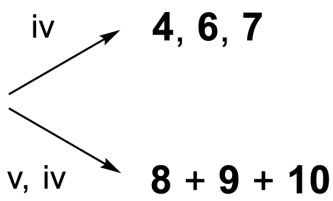

Scheme 1.

General synthetic method for pyrazine containing inhibitors. ${ }^{\mathrm{a}}$

a Reagents and conditions: (i) 2-aminoacetamide, $\mathrm{NaOH}$; (ii) $\mathrm{POCl}_{3}$; (iii) $\mathrm{BOC}$ protected 4(hydroxymethyl)piperidine, $\mathrm{NaH}$; (iv) $\mathrm{HCl}$ in 1,4-dioxane; (v) $\mathrm{Pd}\left(\mathrm{PPh}_{3}\right)_{4}, \mathrm{Zn}(\mathrm{CN})_{2}$. 
<smiles>[R]c1cc(OCC2CCN(C(=O)OC(C)(C)C)CC2)cnc1Cl</smiles><smiles>[R]c1cc(OCC2CCN(C(=O)OC(C)(C)C)CC2)cnc1[R8]</smiles>

$5,11-40$

Scheme 2.

General synthetic method for pyridine containing inhibitors. ${ }^{\text {a }}$

${ }^{a}$ Reagents and conditions: (i) BOC protected 4-(hydroxymethyl)piperidine, $\mathrm{PPh}_{3}$, diisopropyl azodicarboxylate; (ii) $\mathrm{R}^{5}-\mathrm{B}(\mathrm{OH})_{2}, \mathrm{Pd}\left(\mathrm{PPh}_{3}\right)_{4}, \mathrm{Na}_{2} \mathrm{CO}_{3}, 80{ }^{\circ} \mathrm{C}$; (iii) $\mathrm{R}^{6}-\mathrm{B}(\mathrm{OH})_{2}$, $\mathrm{Pd}\left(\mathrm{PPh}_{3}\right)_{4}, \mathrm{~K}_{3} \mathrm{PO}_{4}, 140{ }^{\circ} \mathrm{C}$; (iv) $\mathrm{HCl}$ in 1,4-dioxane. 

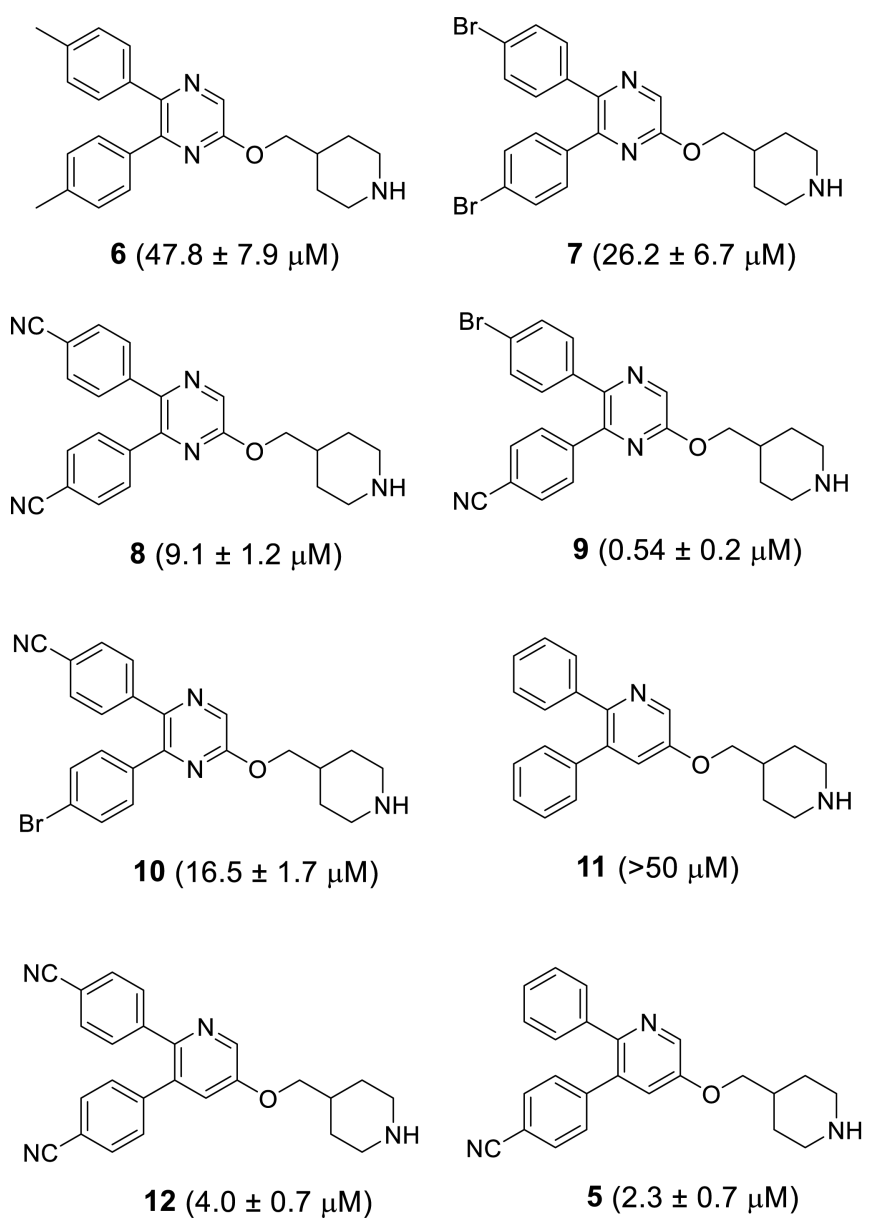

Chart 2.

Structures and $K_{\mathrm{i}}$ values (in parenthesis) of compounds 5 - 12 . 

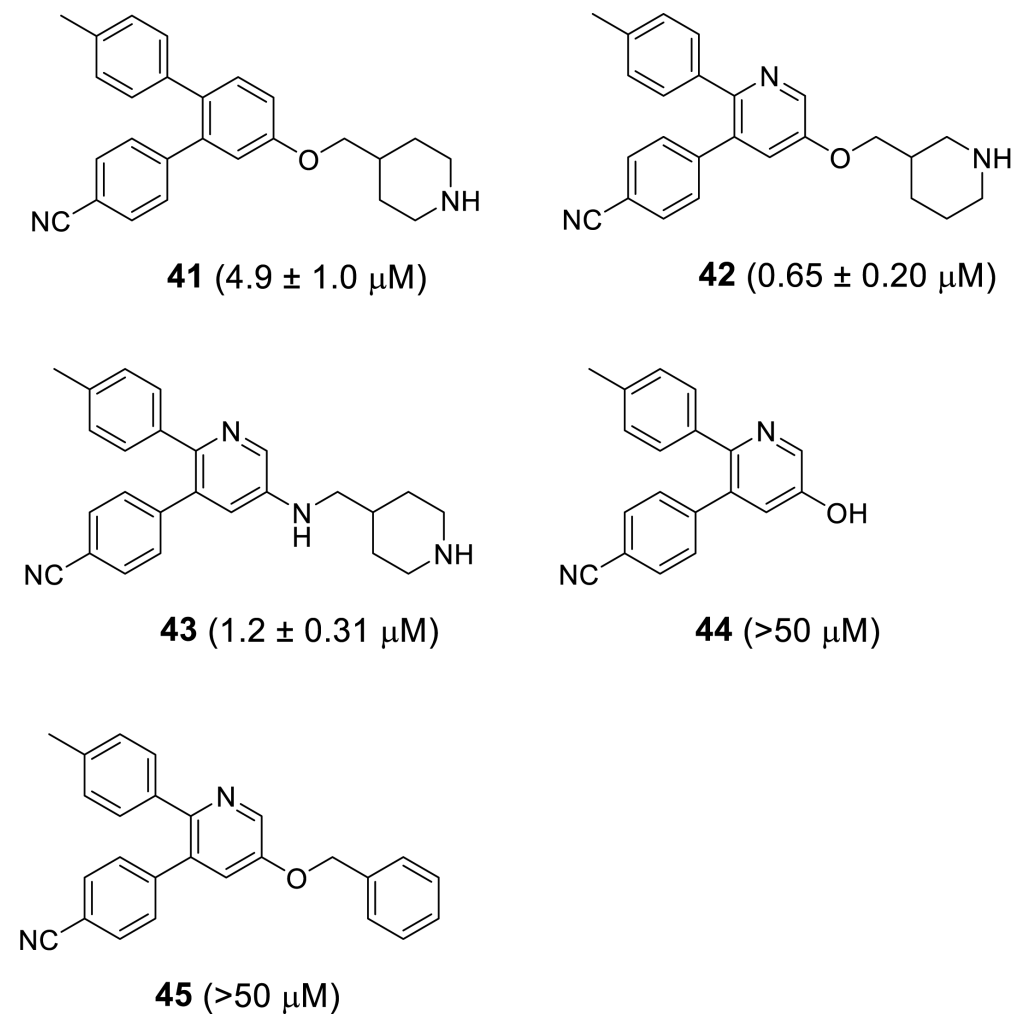

Chart 3.

Structures and $K_{\mathrm{i}}$ values (in parenthesis) of compounds 41 - 45 . 


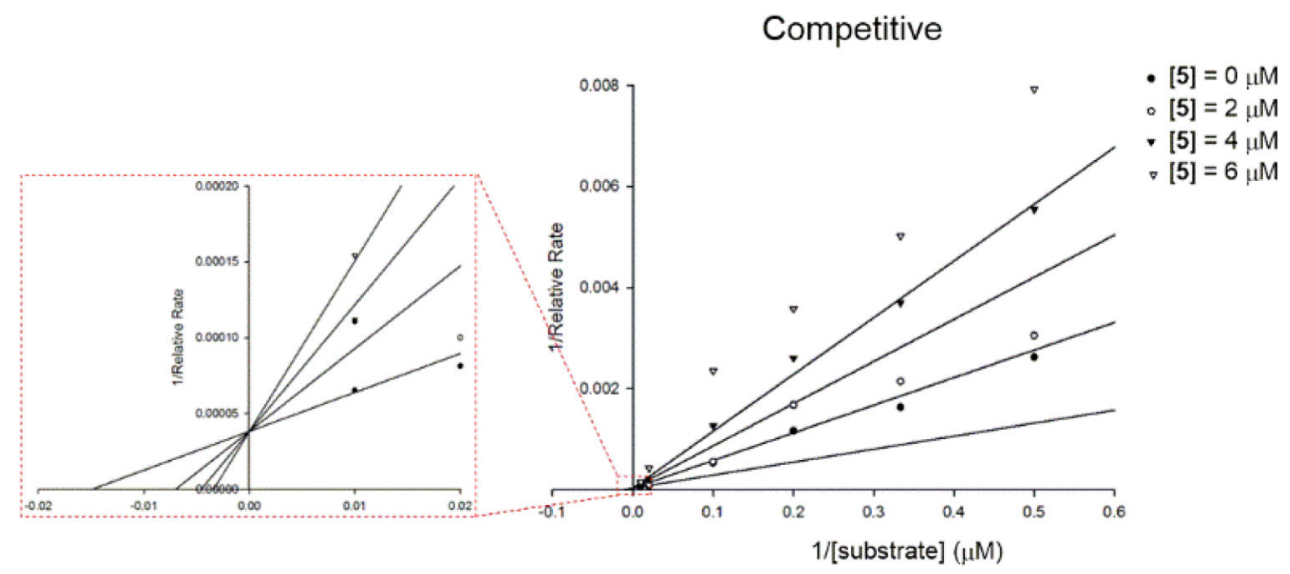

Figure 3.

Lineweaver-Burk plot of competitive inhibition model for compound $\mathbf{5}$ with variable concentrations of the dimethylated $\mathrm{H} 3 \mathrm{~K} 4$ peptide substrate, with an enlarged figure in the left panel showing details near the origin. The $K_{\mathrm{i}}$ was determined to be $1.8 \mu \mathrm{M}$ in this experiment. 
A

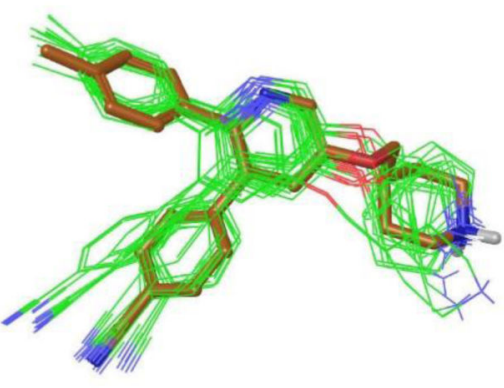

B

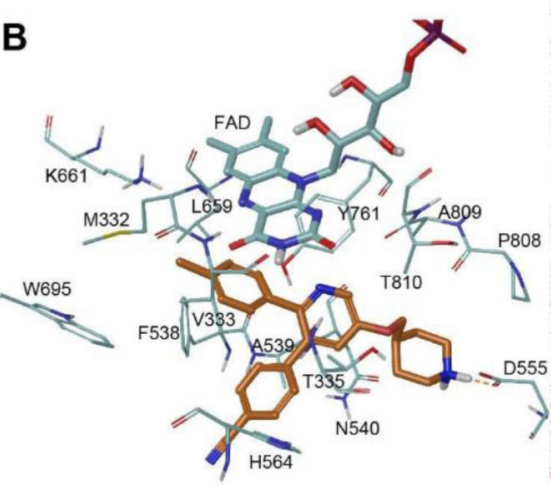

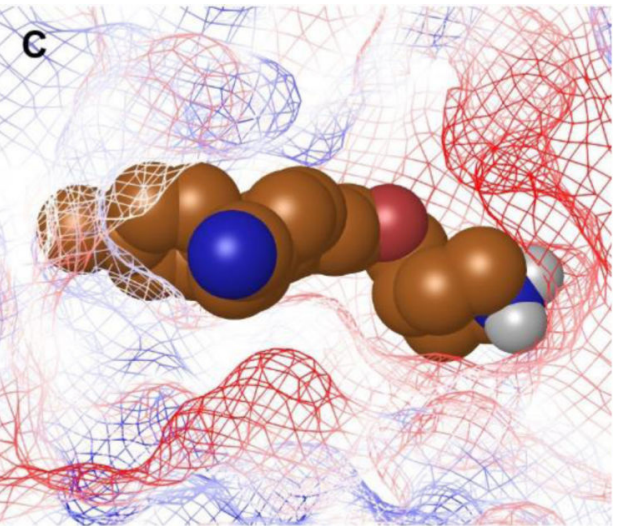

Figure 4.

Docking results of compound 17, using an LSD1 structure (PDB: 2V1D) as the docking template. (A) 20 lowest-energy docking structures of compound 17, with the most stable conformation shown as an orange tube model; (B) The lowest-energy docking structure of 17. Together shown are the interacting key residues (in light cyan) of LSD1 and FAD (light cyan tube model); and (C) The lowest-energy docking structure of $\mathbf{1 7}$ (as a space-filing model) in the active site of LSD1 (shown as a meshed electrostatic potential surface model). 


\section{Compound 17}

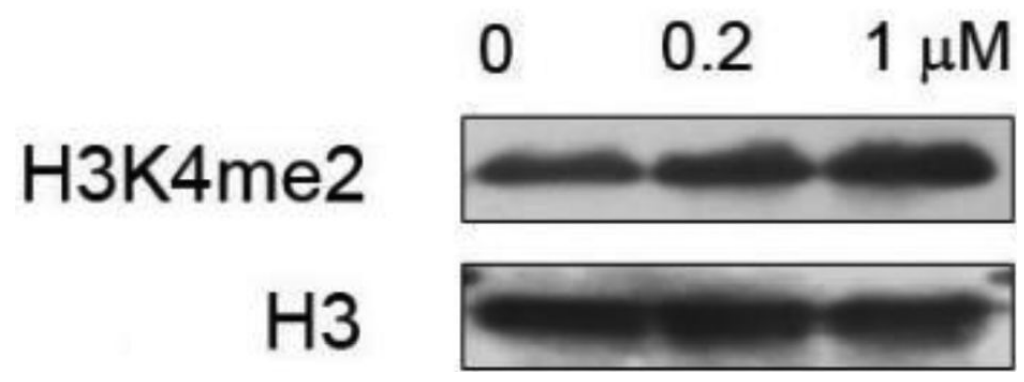

Figure 5.

Treatment of MV4-11 cells with potent LSD1 inhibitor 17 caused an increased cellular level of $\mathrm{H} 3 \mathrm{~K} 4 \mathrm{me} 2$. 


\section{Table 1}

Structures and activity of compounds 5, 12 - 40 .

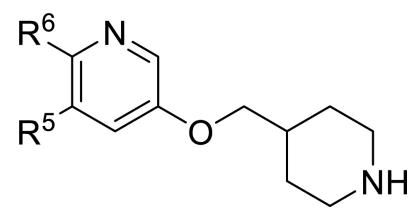

\begin{tabular}{|c|c|c|c|}
\hline & $\mathbf{R}^{5}$ & $\mathbf{R}^{6}$ & $K_{\mathrm{i}}(\mu \mathrm{M})$ \\
\hline 5 & 4-CN-Ph & $\mathrm{Ph}$ & $2.3 \pm 0.7$ \\
\hline 12 & 4-CN-Ph & 4-CN-Ph & $4.0 \pm 0.7$ \\
\hline 13 & 4-CN-Ph & 4-F-Ph & $0.22 \pm 0.07$ \\
\hline 14 & 4-CN-Ph & 3,4-di-F-Ph & $0.57 \pm 0.09$ \\
\hline 15 & 4-CN-Ph & 2,4-di-F-Ph & $1.2 \pm 0.6$ \\
\hline 16 & 4-CN-Ph & $4-\mathrm{CF}_{3}-\mathrm{Ph}$ & $0.058 \pm 0.022$ \\
\hline 17 & 4-CN-Ph & 4-Me-Ph & $0.029 \pm 0.018$ \\
\hline 18 & 4-CN-Ph & 3-Me-Ph & $0.80 \pm 0.21$ \\
\hline 19 & 4-CN-Ph & 4-Et-Ph & $0.20 \pm 0.06$ \\
\hline 20 & 4-CN-Ph & 4-i-Pr-Ph & $0.088 \pm 0.033$ \\
\hline 21 & 4-CN-Ph & 4-OMe-Ph & $0.74 \pm 0.04$ \\
\hline 22 & 4-CN-Ph & $4-\mathrm{OCF}_{3}-\mathrm{Ph}$ & $0.046 \pm 0.011$ \\
\hline 23 & 4-CN-Ph & Pyridin-4-yl & $5.0 \pm 0.6$ \\
\hline 24 & 4-CN-Ph & Pyridin-3-yl & $3.2 \pm 0.7$ \\
\hline 25 & 4-CN-Ph & 4-F-Pyridin-3-yl & $1.8 \pm 0.6$ \\
\hline 26 & 4-CN-Ph & 4-Me-Pyridin-3-yl & $0.38 \pm 0.1$ \\
\hline 27 & 4-CN-Ph & 3-thiophenyl & $2.4 \pm 0.7$ \\
\hline 28 & 4-ethynyl-Ph & 4-Me-Ph & $>50$ \\
\hline 29 & $4-\mathrm{HO}_{2} \mathrm{C}-\mathrm{Ph}$ & 4-Me-Ph & $>50$ \\
\hline 30 & $4-\left(\mathrm{HOCH}_{2}\right)-\mathrm{Ph}$ & 4-Me-Ph & $>50$ \\
\hline 31 & & 4-Me-Ph & $>50$ \\
\hline 32 & & 4-Me-Ph & $>50$ \\
\hline 33 & & 4-Me-Ph & $>50$ \\
\hline
\end{tabular}

J Med Chem. Author manuscript; available in PMC 2017 January 14. 

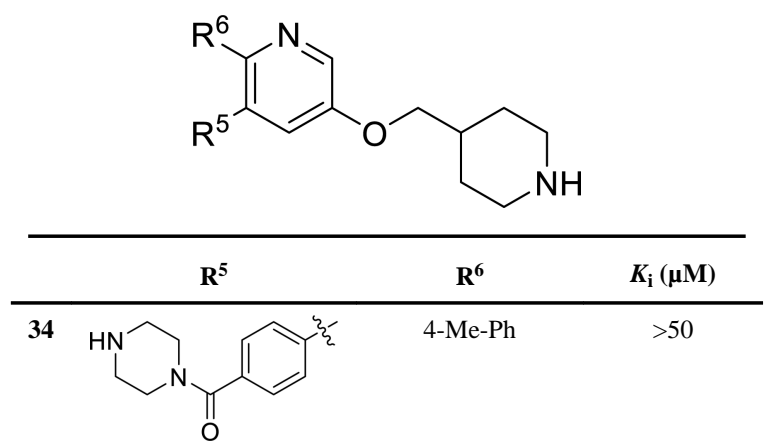

로을

35<smiles>[Y]c1ccc(CNCC)cc1</smiles>

36<smiles>[Y]c1ccc(CN2CCCCC2)cc1</smiles>

37

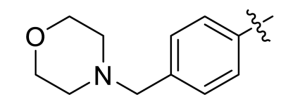

38

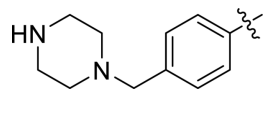

39

2-F-4-CN-Ph

40 3-F-4-CN-Ph
4-Me-Ph

4-Me-Ph

4-Me-Ph

4-Me-Ph

4-Me-Ph

4-Me-Ph
$43.8 \pm 5.7$

$22.3 \pm 1.4$

$>50$

$7.6 \pm 2.1$

$0.22 \pm 0.13$

$0.15 \pm 0.03$

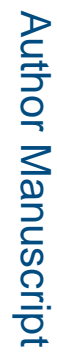

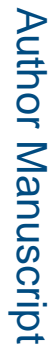

J Med Chem. Author manuscript; available in PMC 2017 January 14. 


\section{Table 2}

Inhibitory activity $\left(K_{\mathrm{i}}, \mu \mathrm{M}\right)$ against MAO-A and -B and selectivity index for LSD1.

\begin{tabular}{ccccc}
\hline & LSD1 & MAO-A & MAO-B & Selectivity index \\
\hline $\mathbf{5}$ & 2.3 & $>50$ & $10.6 \pm 2.8$ & $>4.6$ \\
$\mathbf{1 6}$ & 0.058 & $>50$ & $9.7 \pm 2.9$ & $>160$ \\
$\mathbf{1 7}$ & 0.029 & $>50$ & $18.7 \pm 6.9$ & $>640$ \\
$\mathbf{2 2}$ & 0.046 & $>50$ & $2.6 \pm 1.2$ & $>56$ \\
\hline
\end{tabular}


Table 3

Antiproliferative activity $\left(\mathrm{EC}_{50}, \mu \mathrm{M}\right)$ of LSD1 inhibitors against cancer and normal cells.

\begin{tabular}{ccccccc}
\hline & LSD1 $\boldsymbol{K}_{\mathbf{i}}$ & MV4-11 & Molm-13 & MCF-7 & MDA-MB231 & WI-38 \\
\hline $\mathbf{1 3}$ & 0.22 & $1.1 \pm 0.12$ & $4.4 \pm 1.1$ & $6.9 \pm 1.8$ & $8.6 \pm 2.4$ & $>50$ \\
$\mathbf{1 6}$ & 0.058 & $0.28 \pm 0.03$ & $0.84 \pm 0.18$ & $3.6 \pm 1.5$ & $6.9 \pm 1.9$ & $30.0 \pm 9.2$ \\
$\mathbf{1 7}$ & 0.029 & $0.36 \pm 0.13$ & $3.4 \pm 1.2$ & $3.6 \pm 1.5$ & $5.6 \pm 1.0$ & $26.6 \pm 6.9$ \\
$\mathbf{2 0}$ & 0.088 & $0.30 \pm 0.02$ & $3.2 \pm 1.1$ & $3.3 \pm 0.8$ & $7.6 \pm 2.9$ & $20.0 \pm 4.6$ \\
$\mathbf{2 2}$ & 0.046 & $0.48 \pm 0.12$ & $3.6 \pm 0.5$ & $5.3 \pm 2.2$ & $7.5 \pm 2.2$ & $17.5 \pm 4.8$ \\
$\mathbf{S 2}$ & $0.077^{a}$ & $0.084 \pm 0.026$ & $0.32 \pm 0.1$ & $6.6 \pm 2.0$ & $8.9 \pm 2.5$ & $>50$ \\
\hline
\end{tabular}

${ }^{a}$ IC50 value for compound S2, which is a covalent inhibitor of LSD1. 